\title{
A PRACTICAL APPROACH TO ASSESSING STRUCTURE, FUNCTION, AND VALUE OF STREET TREE POPULATIONS IN SMALL COMMUNITIES
}

\section{by Scott E. Maco and E. Gregory McPherson}

\begin{abstract}
This study demonstrates an approach to quantify the structure, benefits, and costs of street tree populations in resource-limited communities without tree inventories. Using the city of Davis, California, U.S., as a model, existing data on the benefits and costs of municipal trees were applied to the results of a sample inventory of the city's public and private street trees. Results indicate that Davis maintained nearly 24,000 public street trees that provided $\$ 1.2$ million in net annual environmental and property value benefits, with a benefit-cost ratio of 3.8:1. The city can improve long-term stability of this resource by managing maintenance, new plantings, and stand rejuvenation on a city zone basis.
\end{abstract}

Key Words. Urban forest valuation; urban forest management; street tree inventory.

Long-term management, reducing tree program costs, and increasing street trees' ability to maintain benefits depend on sound understanding of the population's structure. Species composition, age complexity, canopy cover, condition, and plantable spaces are telltale indices of urban forest health, stature, management needs, and conflicts. Only by thorough analysis of structure can we begin to value the environmental functions urban trees provide and understand how we, as stewards, can maximize those benefits while reducing costs.

U.S. cities such as Chicago, Illinois, and Modesto, California, have undertaken benefit-cost (B-C) analyses to the great benefit of their municipal tree programs and the residents of their communities (McPherson et al. 1997, 1999a). By analyzing the structure of their city trees and applying values to the functions their city trees provide, these cities not only have proven that their trees' benefits outweigh program costs but have demonstrated how urban forest analyses lead to better tree programs with fewer costs and more public and environmental benefits.

Large cities, however, possess what many small cities or communities do not: the means to conduct the research. Small urban communities [population 2,500-100,000 (U.S. Census Bureau 1995)], with small budgets, usually do not have the resources-whether monetary or technical-to conduct a comprehensive municipal tree analysis of structure, tree growth rates, and benefits and costs.

The U.S. Forest Service's Center for Urban Forest Research has begun production of a series of regional Community Tree Guides to aid planners, local elected officials, landscape architects, urban foresters, and nonprofit groups in quantifying benefits and costs of municipal trees (McPherson et al. 1999b, 2000, 2001, 2002). Through biometric research and municipal forest benefit-cost analysis conducted in a representative city, annual benefits and costs of maintaining "typical" shade trees are described. Cities in the same region can combine street tree growth data from the representative city with their sample street tree inventory to calculate benefits. This paper describes an approach for accomplishing this goal in small communities.

\section{METHODS}

Using the city of Davis, California, as a model, this project combined the rapid sampling technique proposed by Jaenson et al. (1992) with existing data published by the U.S. Forest Service's Center for Urban Forest Research (McPherson et al. 1999a) to develop an expedient and low-cost approach for analyzing street tree populations in small communities. This model produces four types of information:

- resource structure (species composition, diversity, age distribution, condition, etc.)

- resource function (magnitude of environmental and aesthetic benefits)

- resource value (dollar value of benefits realized)

- resource management needs (sustainability, canopy cover, pruning and young tree care, planting, and conflict mitigation)

As illustrated in Figure 1, this section describes the inputs and calculations necessary to derive the aforementioned outputs: conducting the sample inventory, calculating the resource's structural attributes, using the Community Tree Guide to estimate magnitude of benefits provided, assessing resource unit values, assessing costs of street tree management, calculating net benefits and benefit-cost ratio, and determining management needs. 


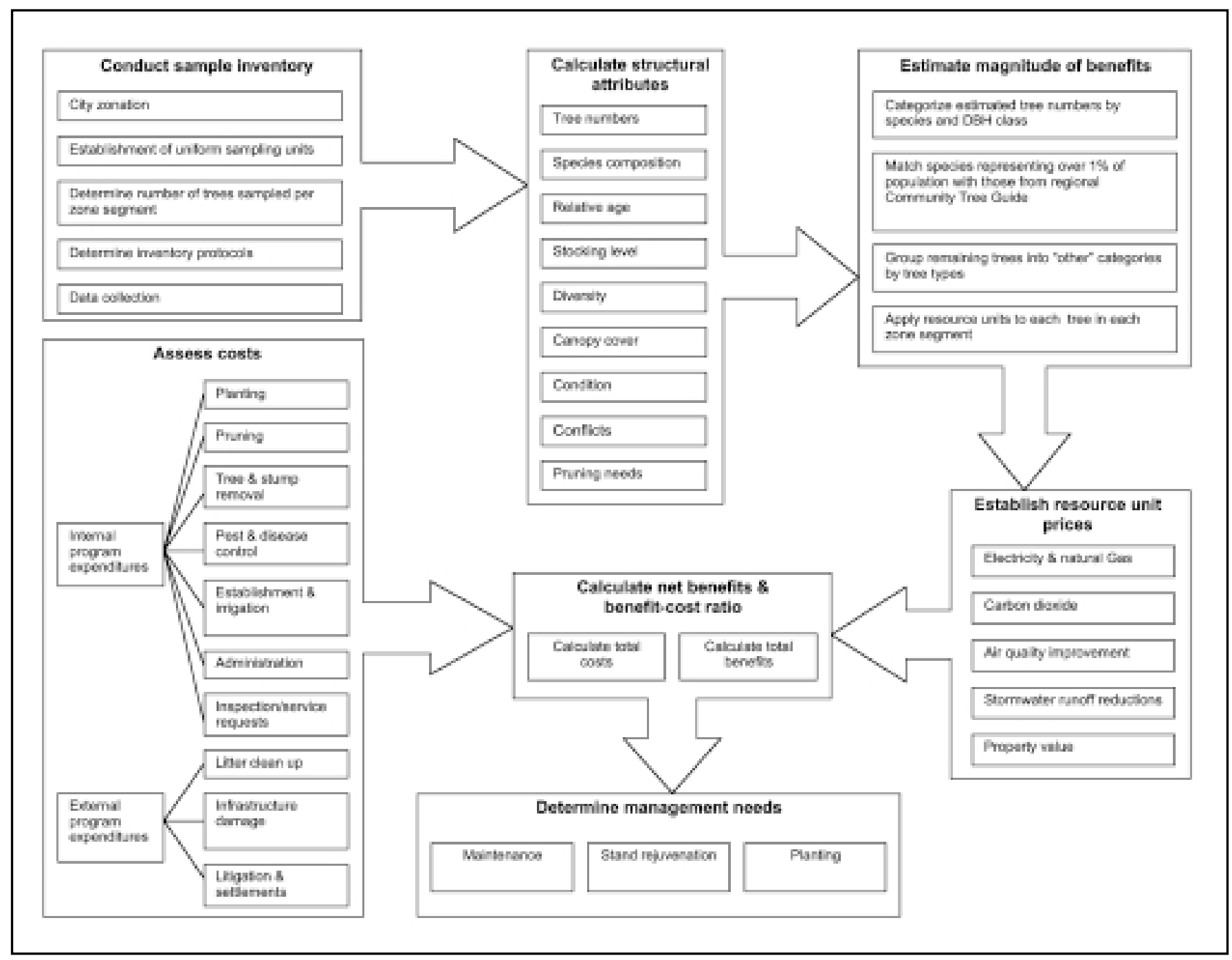

Figure 1. Process flow chart.

\section{Study Area}

The city of Davis is located along the border of Yolo and Solano counties in the Central Valley. It lies approximately 21 $\mathrm{km}$ west of California's capital city, Sacramento, and $143 \mathrm{~km}$ north of the city of Modesto. The greater Central Valley region-bounded by the Sierra Nevada Mountains to the east and the Coastal Range to the west-exhibits a Mediterranean climate characterized by hot, dry summers and cool, wet winters. At an average city elevation of $15 \mathrm{~m}$, the annual average temperature in Davis ranges from $10^{\circ} \mathrm{C}$ to $17^{\circ} \mathrm{C}$, and the maximum temperature, occurring in July and August, averages $35^{\circ} \mathrm{C}$ to $37^{\circ} \mathrm{C}$ (Wells 1972). The average growing season is 258 days per year, and the average frost-free period begins in early February. Precipitation for the year averages 420 mm, with 90\% falling between November and April.

Incorporated in 1917, Davis currently has a population of approximately 58,600 (DOF CA 2001), is approximately 24.5 $\mathrm{km}^{2}$ in area, and has $249 \mathrm{~km}$ of public streets (City of Davis 2001).
CONDUCTING THE SAMPLE INVENTORY

Based on the principle of stratified random sampling, Jaenson et al. (1992) outlined a sample tree inventory method requiring no level of preexisting information, such as knowing the total number of existing street trees in the city. With their method, street tree information, including species composition, dbh, health, total number of trees, and vacant planting spaces, were affordably and reliably collected and analyzed, providing a database that yielded accurate baseline information pertaining to the function and structure of the vegetation resource on both a citywide and management zone (neighborhood) level (Figure 2). This sampling technique has been described elsewhere; however, a brief summary of the authors' steps and an introduction to terminology is warranted here. 


\section{City of Davis Zone Segment Map}

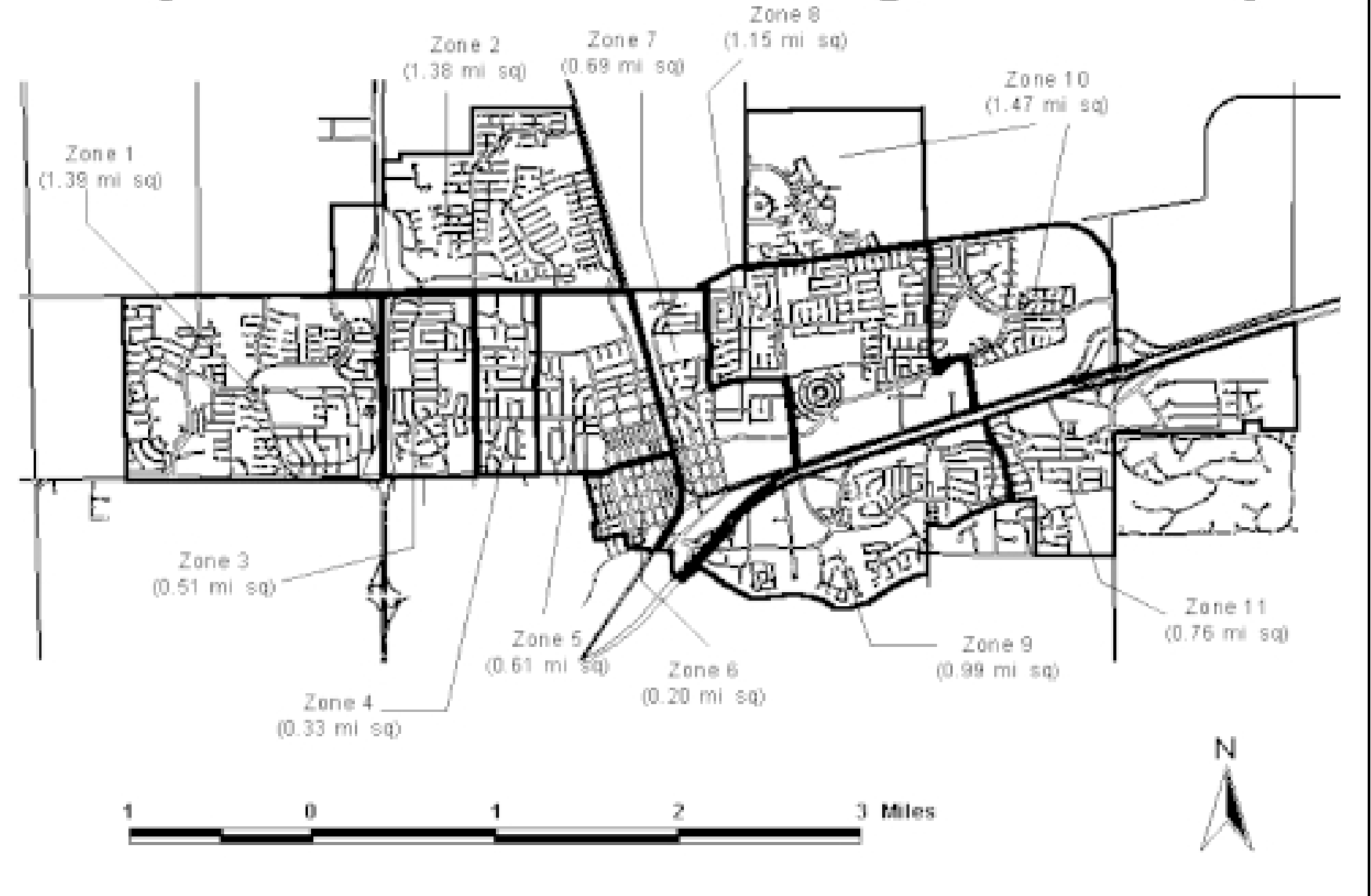

Figure 2. Zone segment and city area map.

The first step is to stratify the city's area into homogenous zone segments based on street layout and naturally delineating characteristics (neighborhood age, political boundaries, etc.). Each zone segment is then divided into sampling units - uniform blocks, or equivalent street segments, that will be randomly sampled throughout the city. To determine the distribution of the approximately 2,300 trees to be sampled among zone segments, a pre-sample is then conducted to estimate zone segment street tree density, or average number of trees per sampling unit, in each of the zone segments. Based on the results of this "windshield" survey, the desired number of sampling units to be inventoried per zone segment can be calculated and drawn randomly. The final step includes surveying each tree, within each randomly chosen sampling unit. Any number of structural attributes (species, dbh, tree maintenance priorities, plantable spaces, etc.) can be recorded on paper or directly into a palmtop computer for analysis.

Assuming no preexisting knowledge regarding the street tree resource in Davis, the method, described in Jaenson et al. (1992), was followed precisely. However, the use of the sampling method in sampling privately cared-for street trees and calculating results (the populations' structural attributes) is addressed because these procedures differed from Jaenson's protocols.

Inventory Protocols. After determining the number of sampling units to be inventoried per zone segment, all trees in the city right-of-way (ROW) within each unit were surveyed, with basic size and condition measurements collected as necessary to understand desired structural attributes of the population (Figure 1). In addition to the public street trees targeted for inventory, private street trees-those found within the ROW but not maintained by the city-were sampled. Only those private trees located in zone segments randomly selected for inventory of public trees were inventoried. Two-person teams (a measurer and a recorder) were used to record data onto a tally sheet, later entered into a computer spreadsheet for data analysis. 


\section{Calculating Structural Attributes}

As Jaenson et al. (1992) described, the pre-sampling procedure was used to initially determine the proportion of individual trees in each zone segment and, subsequently, the sampling intensity targeted for each zone. The result was a proportional allocation of the number of sampling units sampled per zone segment that yielded a self-weighting sample, simplifying subsequent calculations of population estimates (Cochran 1977). Consequently, the application of the weighting procedure (step 12 in Jaenson et al. 1992) was found to be an unnecessary step due to the proportional sampling fraction in all strata (zone segments). Therefore, citywide total numbers of individual tree species $(X)$ and their attributes were estimated based on the proportions of trees counted in the actual sample inventory, not the pre-sample. The model for stratified random sampling with proportional allocation (Cochran 1977) was used to make the calculation:

$$
\begin{aligned}
& \bar{y}=\frac{\sum_{h=1}^{L} n_{h} \bar{y}_{h}}{n}, \text { where } \\
& y_{h}=\frac{\sum_{i=1}^{n_{h}} y_{h i}}{n_{h}} \\
& L=\text { number of strata } \\
& n_{h}=\text { number of units in sample } \\
& y_{h i}=\text { value obtained for the ith unit }
\end{aligned}
$$

Following Equation 1, zone segment (Equation 2) and citywide (Equation 3) totals for each inventoried species were calculated:

Estd. $\#$ of species $X$ per zone segment $=$

$\left(\begin{array}{l}\text { Actual \# of sampling } \\ \text { units per zone segment }\end{array}\right) *\left(\begin{array}{l}\text { Total \# of species } X \text { counted in zone segment } \\ \# \text { of sampling units sampled in zone segment }\end{array}\right)$

Estd. \# of each species $X$ citywide $=\sum$ Estd. $\#$ of species $X$ per zone segment

Estimating the percentage of the citywide population represented by species $X$ was calculated with Equation 4:

Species $X$ as a percentage of population $=\left(\frac{\text { Estd. number of species } X}{\sum \text { Estd. number of all city trees }}\right)$

These calculations were repeated for inventoried attributes of both public and private trees.

\section{Estimating Magnitude of Benefits}

As precursor to the Community Tree Guide series (McPherson et al. 1999b, 2000, 2001, 2002), McPherson et al. (1999a) conducted a benefit-cost analysis of municipal trees in Modesto, California, a city located in the Central Valley with a climate similar to Davis. Twenty-one of Modesto's most abundant species were inventoried in a twostrata random sample of young and old trees. Crown volume and leaf-surface area (LSA) were estimated using methods of digital image processing described by Peper and McPherson (1998). Nonlinear regression was used to fit a predictive model for $\mathrm{dbh}$ as a function of age for each species. Predictions of LSA, crown diameter, and tree height were modeled as a function of dbh using the same model as dbh versus age (Peper et al. 2001).

Defined as resource units, the absolute value of the benefits of Modesto's public trees-electricity ( $\mathrm{kWh} / \mathrm{tree})$ and natural gas savings ( $\mathrm{kBtu} / \mathrm{tree})$, atmospheric $\mathrm{CO}_{2}$ reductions (kg/tree), air quality improvement $\left[\mathrm{NO}_{2}, \mathrm{PM}_{10}\right.$, and VOCs (kg/tree)], stormwater runoff reductions [precipitation interception $\left(\mathrm{m}^{3} /\right.$ tree $\left.)\right]$, and property value increases $\left[\Delta \mathrm{LSA}\left(\mathrm{m}^{2} /\right.\right.$ tree $\left.)\right]$ —were assigned prices through direct estimation and implied valuation as externalities. To infer from the 21 sampled species to the remaining species, called "Other Street Trees," each tree was categorized based on

small (BDS)

- broadleaf evergreen-large (BEL), medium (BEM), and small (BES)

- conifer-large (CL), medium (CM), and small (CS)

Large, medium, and small trees measured $>15 \mathrm{~m}, 8$ to 15 $\mathrm{m}$, and $<8 \mathrm{~m}$, respectively. A typical tree was chosen for each of the above nine categories to obtain growth curves for "other" trees falling into each of the categories.

Estimating the magnitude of benefits (resource units) produced by street trees in Davis required four procedures (Figure 1): (1) categorizing Davis street trees by species and dbh based on results of the sample inventory, (2) matching significant species with those from a regional Tree Guide, (3) grouping remaining "other" trees by type, and (4) applying resource units to each tree in each zone segment.

\section{Categorizing Trees by dbh Class.}

The dbh values for each of the published six age classes $(5,15,25,35,45$, and 55 years after planting) were obtained from the authors for the 21 
species sampled in Modesto. None of these species fell into the BES, CM, and CS tree type classes. Therefore, three additional substitutes were added so that all nine classes would be represented: "BES Other" was scaled at onethird of the dbh values for holly oak (Quercus ilex); "CM Other" and "CS Other" were scaled at twothirds and onethird, respectively, of Japanese black pine (Pinus thunbergii). Table 1 shows dbh values for the 21 Modesto species along with the three remaining tree type substitutes.

With the dbh values presented in Table 1 and the known resource unit values for each benefit of each tree at each age class, data were in place to infer resource unit values to Davis's trees. Because tree age is typically not known and, therefore, not included in municipal street tree inventories, the first step in accomplishing this task involved categorizing the estimated total number of Davis's public trees by relative age (dbh class). Results of the sample inventory were used to group trees-both citywide and by zone segments-using the following classes:

$\begin{array}{ll}\text { 1. } & 0 \text { to } 7.5 \mathrm{~cm} \\ \text { 2. } & 7.6 \text { to } 15.1 \mathrm{~cm} \\ \text { 3. } & 15.2 \text { to } 30.4 \mathrm{~cm} \\ \text { 4. } & 30.5 \text { to } 45.6 \mathrm{~cm} \\ \text { 5. } & 45.7 \text { to } 60.9 \mathrm{~cm} \\ \text { 6. } & 61.0 \text { and } 76.2 \mathrm{~cm} \\ \text { 7. } & >76.2 \mathrm{~cm}\end{array}$

These classes served as a surrogate for the evaluation of benefits in lieu of the age classes used in the Modesto analysis. Because dbh classes represented a range, the median value for each dbh class was determined and subsequently utilized as a single value representing all trees encompassed in each class. Linear interpolation was used to estimate resource unit values (Y-value) for each of the 21 Modesto species for the seven midpoints (X-value) corresponding to each of the dbh classes assigned to Davis's street trees.

Matching Significant Species with Community Tree

Guide. To infer from the 21 Modesto species to Davis's public street tree population, each species representing more than $1 \%$ of the population citywide, and by zone, was matched directly with corresponding Modesto species or, where there was no corresponding tree, the best match was determined by identifying which of the 21 species was most similar in size, leaf shape/type, habit, and tree type. For example, the sample inventory contained 98 public street tree species of which only 28 represented $1 \%$ or more of the total Davis population. Of these 28 species, 14 corresponded directly with the taxa sampled in Modesto. The 14 remaining species were matched with the next closest species: Davis's Aristocrat flowering pear (Pyrus calleryana 'Aristocrat') with Modesto's Bradford pear (P. calleryana 'Bradford'); Davis's Arizona ash (Fraxinus velutina) with Modesto's Modesto ash (F. velutina 'Modesto'); Davis's cork oak (Quercus suber) with Modesto's holly oak (Q. ilex); and so forth.

Grouping Remaining “Other” Trees by Type. The 70 species that were less than $1 \%$ of the population were labeled "other" and were categorized according to tree type classes (see above). To obtain resource values for these nine other categories, a typical species was selected from Table 1 to represent Davis trees falling into each category:

BDL Other $=$ London plane tree $($ Platanus $\times$ acerifolia $)$ BDM Other $=$ Chinese pistache (Pistacia chinensis)

BDS Other $=$ crape myrtle (Lagerstroemia indica)

BEL Other = holly oak (Quercus ilex)

BEM Other $=$ camphor tree (Cinnamomum camphora)

BES Other = BES Other (no trees present in Davis)

CL Other = Japanese black pine (Pinus thunbergii)

CM Other = CM Other (no trees present in Davis)

CS Other = CS Other (no trees present in Davis) 
Applying Benefit Resource Units to Each Tree. Once categorized, the interpolated resource unit values were matched on a one-for-one basis. For example, the sample inventory results suggested that out of 1,483 Chinese hackberry trees in Davis, 197 were within the 7.6 to $15.1 \mathrm{~cm}$ dbh class size. The interpolated electricity and natural gas resource unit values for the class size midpoint $(11.4 \mathrm{~cm})$ were $15.2 \mathrm{kWh} /$ tree and $17.9 \mathrm{kBtu} /$ tree, respectively. Therefore, multiplying the size class resource units by 197 equals the magnitude of annual heating and cooling benefits produced by this segment of the population: $2.9 \mathrm{MWh}$ in electricity savings and 3.5 MBtu natural gas savings. This information-resource units, on a per tree basis by dbh class - is available for each of the significant species (approximately 20 species) for each regional Community Tree Guide.

\section{Establishing Resource Unit Prices}

As detailed above, the methods used to derive resource units of environmental benefits, on a per tree basis, were unaltered with respect to the Modesto analysis. Described below are the methods used to derive resource unit prices specific to the city of Davis.

Electricity and Natural Gas. Lacking empirical data regarding the percentage of electricity and natural gas use above baseline levels in Davis, dollar values per unit were based on conservative baseline prices, using average, local Pacific Gas \& Electric Company (PG\&E) utility prices for Davis's fiscal year preceding the sample inventory-July 1 , 1999 through June 30, 2000. Electricity savings were valued at $\$ 0.116 / \mathrm{kWh}$ (PG\&E 2001a) and natural gas at $\$ 0.64 /$ therm (PG\&E 2001b).

Atmospheric Carbon Dioxide Reduction. Reductions in $\mathrm{CO}_{2}$ as a by-product of electricity generation were assumed the same in Davis as in Modesto. This assumption is likely an underestimation of the net avoided $\mathrm{CO}_{2}$ emissions because PG\&E relies more heavily on fossil fuels for generating capacity than Modesto's local utility. But because PG\&E purchases a significant portion of their electricity from nonspecific suppliers, specific emissions rates were difficult to estimate and thus deferred to known Modesto values. As in Modesto, $\mathrm{CO}_{2}$ was valued using control costs recommended by the California Energy Commission (1994) at $\$ 0.033 / \mathrm{kg}$.

Air Quality Improvement. Values for resource units were applied using criteria pollution emission reduction credit (ERC) transaction costs specific of 0.33 . to the Yolo-Solano Air Quality Management District (California Air Resources Board 2000, 2001). Control cost values were obtained by using the weighted average (tons sold per unit price) for all transactions made during the 2-year span 1999-2000: $\mathrm{NO}_{2}=\$ 8.48 / \mathrm{kg}, \mathrm{PM}_{10}=\$ 9.84 / \mathrm{kg}$, and VOCs $=$ $\$ 3.32 / \mathrm{kg}$.

Stormwater Runoff Reductions. Total capital investments associated with stormwater management in Davis totaled approximately $\$ 50$ million and included all system infrastructure: drainage/transit pipes and channels, detention basins, settling ponds, and pump stations (Terry Jue, Public Works Department, City of Davis, California, pers. comm., April 27, 2001). Annualized over 40 years-the time estimated for complete reinvestment - this amount resulted in an annual average capital expenditure of $\sim \$ 1,252,000$. Operations and management (including administrative salaries) of this infrastructure in FY 1999-2000 was $\$ 514,000$. The combined yearly expenditure was therefore estimated at $\$ 1,766,000$.

As shown in Table 2, an essential component in understanding runoff of stormwater is the evaluation of each type of land area and its effectiveness in producing runoff. Lacking land-use data for Davis, classifications were based on percentages from Olympia, Washington (City of Olympia 1995).

Using Equation 5, total stormwater runoff in Davis $\left(R_{\mathrm{D}}\right)$ was estimated at 3,533,921 $\mathrm{m}^{3}(933,526,909$ gal) per year

$$
R_{\mathrm{D}}=A \times E_{\mathrm{is}} \times P
$$

where

$A=$ Total land area $(2,455.37 \mathrm{ha})$

$E_{\text {is }}=$ Total effective impervious surface (33.1\%)

$\mathrm{P}=$ Average annual precipitation $(436.14 \mathrm{~mm})$

Dividing total annual expenditures by total stormwater runoff implies that the city spent $\$ 0.499 / \mathrm{m}^{3}$ of stormwater managed.

Effective interception is the proportion of precipitation intercepted by a tree that would otherwise result in direct

Table 2. Davis land area classified to determine the citywide effective runoff coefficient

\begin{tabular}{|c|c|c|c|c|}
\hline Lenduse & $\begin{array}{c}\text { Total Area } \\
\text { (ha) }\end{array}$ & $\begin{array}{c}\% \text { of Total } \\
\text { Area }\end{array}$ & $\begin{array}{l}\text { Effective } \\
\text { runoff } \\
\text { coefficient }\end{array}$ & $\begin{array}{c}\text { Weighted Average } \\
\text { (\% of tDL } x \text { runoff coefficient) }\end{array}$ \\
\hline Low densily residential & 81027 & 33 & 0.04 & 0.013 \\
\hline High density residential " " & 95759 & 39 & 0.26 & 0.101 \\
\hline Multifamily residential "'- & 19643 & 8 & 0.49 & 0.037 \\
\hline Commencialîndustrial & 51563 & 21 & 0.87 & 0.180 \\
\hline Total & 247992 & 100 & 1.66 & 0.331 \\
\hline \multicolumn{5}{|c|}{$\begin{array}{l}\text { "Estimate of all city areas that have less than } 1 \text { dwellinglunit per acre and includes parks, } \\
\text { open spece, green belts, agricultural land, golf courses, etc. } \\
\text { "Estimate of typical single-family suburtan residential area (3-7 units/acre). } \\
\text { "*Estimate of land area occupied by mult-family residential housing (7-30 units/acre). }\end{array}$} \\
\hline
\end{tabular}


surface runoff-a factor that must be accounted for in valuing effectiveness in reducing stormwater management costs. Because the Modesto data relied on total interception to calculate benefits of stormwater, a price adjustment factor of 0.91 was used to calculate effective interception from total interception as reported in the Modesto analysis. This factor assumes an initial abstraction of $2 \mathrm{~mm}$ for the average city ROW based on computations of runoff curves for land area as described in the Natural Resources Conservation's Technical Release-55 (NRCS 1986). In other words, small rainfall events of less than $2 \mathrm{~mm}$ are not likely to produce direct runoff and are therefore excluded in valuing stormwater reduction benefits. Therefore, the adjusted value of rainfall intercepted by street trees was $\$ 0.455 / \mathrm{m}^{3}$.

Property Value. In an Athens, Georgia, study (Anderson and Cordell 1988), a large front-yard tree was found to be associated with a $0.88 \%$ increase in average home resale values. Along with identifying the average (weighted) LSA of a mature large tree in Davis $\left(\sim 400 \mathrm{~m}^{2}\right)$ and using the average annual change in LSA $\left(\mathrm{m}^{2}\right)$ for trees within each dbh class as a resource unit, this increase was the basis for valuing trees' capacity to increase property value.

Assuming the $0.88 \%$ increase in property value held true for Davis, each large tree would be worth $\$ 2,412$ based on the average single-family home resale prices in Davis $(\$ 273,518)$, averaged for the months beginning July 1999 and ending June 2000 (Yolo County Association of Realtors 2001). However, not all trees are as effective as front-yard residential trees in increasing property values. For example, trees adjacent to multifamily housing units will not increase the property value at the same rate as trees in front of a singlefamily home. Therefore, a citywide reduction factor (0.92) was applied to prorate trees' value based on the assumption that trees adjacent to differing land-use-single home residential, multi-home residential, commercial, and other (vacant, institutional, etc.) -were valued at 100\%, 75\%, 67\%, and $50 \%$ of the full $\$ 2,412$ (McPherson et al. 2001).

Given these assumptions, a typical large tree was estimated to increase property values by $\$ 5.53 / \mathrm{m}^{2}$ of LSA.

For example, it was estimated that a single Chinese pistache adds about $2.16 \mathrm{~m}^{2}$ of LSA per year when growing in the dbh range of 30.5 to $45.6 \mathrm{~cm}$. During this period of growth, therefore, pistache trees effectively added $\$ 10.92$, annually, to the value of a home, condominium, or business property $\left[\left(2.16 \mathrm{~m}^{2} \times \$ 5.53 / \mathrm{m}^{2}\right) \times 92 \%=\$ 10.92\right]$.

Assessing Costs. Total costs associated with the management of Davis's public street trees were difficult to assess due to the lack of record keeping outside the Parks and Open Space Management Division. The Public Works Department does not currently keep records regarding specific costs of infrastructure repair expenditures attributed to city street trees. Likewise, the City Manager's Office reported having no available records of liability costs associated with city-managed street trees. Leaf litter from city street trees was collected as part of the city's green waste contract with Davis Waste Removal (DWR), and no discernable itemization in the contract was made between private yard waste and city-owned trees.

Internal costs (Figure 1) for all expenditures for FY 1999-2000 were identified through a survey completed by the Senior Park Supervisor. Due to the unavailable cost data from city sources, two external expenditures-those outside the division-related to annual liability and infrastructure repair, were inferred from 1996 figures reported in McPherson's (2000) survey of 18 California cities' expenditures on tree-related damage; dollar values for FY 19992000 were $\$ 24,818$ after adjusting for inflation. Legal cost information was not reported by Davis in the survey and was therefore inferred to be $\$ 22,447$ based on the mean per capita cost of all reporting cities. Litter removal/disposal costs were assumed to be $\$ 6,317$, based on $40 \%$ of 385 tons (\$41.02/ton) of litter removed during the autumn leafdrop period for DWR's FY 2000 (J. Geisler, Davis Waste Removal, Davis, California, pers. comm., May 1, 2001).

\section{Calculating Net Benefits and Benefit-Cost Ratio}

To assess the total value of annual benefits (B) for each street tree $(i)$ in each zone segment $(j)$, benefits were summed:

$$
B=\sum_{1}^{n} j\left(\sum_{1}^{n} i\left(e_{i j}+a_{i j}+c_{i j}+h_{i j}+p_{i j}\right)\right)
$$

where

$e=$ price of net annual energy savings $=$ annual natural gas savings + annual electricity savings

$a=$ price of annual net air quality improvement $=\mathrm{PM}^{10}$

interception $+\mathrm{NO}_{2}$ absorption $+\mathrm{O}_{3}$ absorption

$c=$ price of annual carbon dioxide reductions $=\mathrm{CO}_{2}$

sequestered less releases $+\mathrm{CO}_{2}$ avoided from reduced energy use

$h=$ price of annual stormwater runoff reductions = effective $\mathrm{H}_{2} \mathrm{O}$ interception

$p=$ price of aesthetics $=$ annual increase in property value

Total net expenditures were calculated based on all identifiable internal and external costs (Figure 1) associated with the annual management of Davis's street trees citywide. Annual costs for public street trees $(C)$ were summed:

$$
C=p+t+r+d+e+s+c+l+a+q
$$

where

$p=$ annual planting expenditure

$t=$ annual pruning expenditure 
$r=$ annual tree and stump removal and disposal expenditure

$d=$ annual pest and disease control expenditures

$e=$ annual establishment/irrigation expenditure

$s=$ annual price of repair/mitigation of infrastructure damage

$c=$ annual price of litter/storm cleanup

$l=$ average annual litigation and settlement expenditures

due to tree-related claims

$a=$ annual expenditure for program administration

$q=$ annual expenditures for inspection/answer service

requests

Total citywide annual net benefits as well as the benefitcost ratio (BCR) were calculated using the sums of benefits and costs:

$$
\begin{gathered}
\text { Citywide net benefits }=B-C \\
\text { BCR }=B / C
\end{gathered}
$$

\section{RESULTS AND DISCUSSION \\ Resource Structure}

The completed sample inventory included 2,393 public trees and an additional 696 private trees located within the city's ROW. This sample represented approximately $10 \%$ of the estimated citywide population of street trees.

Tree Numbers. Estimated numbers and proportions of trees found citywide and by zone segment are shown in Table 3. The estimated citywide population of city street trees totaled $23,810( \pm 1,396)$. The public tree population combined with the private tree population within the city ROW put the total number of street trees at over 31,000 $( \pm 1,476)$. Population totals varied by zones, however. For example, nearly $20 \%$ of all city trees were found in residential zone segment 1 (Figure 2), while the downtown core area represented less than $4 \%$ of the population.

The standard errors (se) of the zone segment populations varied but were typically within $15 \%$ to $20 \%$ of the estimated number. Error in citywide population estimates matched Jaenson et al.'s (1992) finding that error of citywide totals did not exceed 10\%; all estimates for Davis had a se between $5 \%$ and $7 \%$.

\section{Species Composition and} Diversity. Only London plane (Platanus x acerifolia) exceeded the commonly held standard that no single species should represent more than $10 \%$ of the total population (Clark et al. 1997). However, examination of zone segments belied this interpretation. In every zone segment, two or more species contributed from $20 \%$ to more than $50 \%$ of the zone's population. In several

\begin{tabular}{|c|c|c|c|c|c|c|}
\hline & $\begin{array}{c}\text { Esti } A d \text { oity } \\
\text { trees }\end{array}$ & $\begin{array}{c}\text { Estr. A of } \\
\text { privgte trees }\end{array}$ & $\begin{array}{c}\text { Estd. fota \# of } \\
\text { trees (clly and } \\
\text { private) }\end{array}$ & $\begin{array}{c}\text { Estd. \% of cty } \\
\text { tree } \\
\text { populaton }\end{array}$ & $\begin{array}{l}\text { Esid. } \% \text { of } \\
\text { privale tree } \\
\text { population }\end{array}$ & $\begin{array}{c}\text { Esid. \% of } \\
\text { Iotal } \\
\text { population is } \\
\text { privale tees }\end{array}$ \\
\hline Zone segment 1 & $4,579(828)$ & $1,500(222)$ & $6,079(854)$ & 192 & 20.7 & 24.7 \\
\hline Zore segnent 2 & 2.999 (545) & $1,602(295)$ & $4601(615)$ & 12.6 & 221 & 348 \\
\hline Zore segment 3 & 1.234 (196) & $333(87)$ & $1,566(212)$ & 52 & 4.6 & 21.2 \\
\hline Zore segnent 4 & $846(195)$ & $315\langle 65\rangle$ & $1,161(213)$ & 3.6 & 4.3 & 27.1 \\
\hline Zone segment 5 & $1,775(324)$ & $483(87)$ & 2,258 (338) & 7.5 & 6.7 & 21.4 \\
\hline Zore segnent 6 & $B 82(212)$ & $53(25)$ & 935 (212) & 3.7 & 0.7 & 57 \\
\hline Zone segment 7 & $1,502(334)$ & $390(85)$ & 1,901 (349) & 6.3 & 5.5 & 21.0 \\
\hline Zone segment 8 & $3,140(477)$ & $1,434(225)$ & $4,575(531)$ & 132 & 19.8 & 31.0 \\
\hline Zone segment 9 & $2,128(445)$ & $\Delta 60(91)$ & $2,588(457)$ & 8.9 & 6.3 & 17.8 \\
\hline Zore segment 10 & 3,340 (381) & $373\langle 80\rangle$ & $3,713(386)$ & 140 & 5.1 & 100 \\
\hline Zore segment 11 & $1,385(209)$ & $305(72)$ & $1,691(244)$ & 58 & 4.2 & 180 \\
\hline Conpwide Totals & $23,810(1,396)$ & $7,256(484)$ & $31,065(1,476)$ & 100 & 100 & 23.4 \\
\hline
\end{tabular}

Table 3. Public and private street tree population estimates (se in parentheses). 
Table 4. Simpson's diversity index by zone (C).

\begin{tabular}{cccc}
\hline Zone & $\begin{array}{c}\text { Public } \\
\text { Trees }\end{array}$ & $\begin{array}{c}\text { Privase } \\
\text { Trees }\end{array}$ & $\begin{array}{c}\text { Public 8 } \\
\text { Private } \\
\text { Troes }\end{array}$ \\
\hline $\mathbf{1}$ & 0.08 & 0.06 & 0.06 \\
2 & 0.12 & 0.05 & 0.07 \\
$\mathbf{3}$ & 0.05 & 0.09 & 0.05 \\
$\mathbf{4}$ & 0.16 & 0.12 & 0.10 \\
$\mathbf{5}$ & 0.09 & 0.05 & 0.06 \\
$\mathbf{6}$ & 0.14 & 0.22 & 0.12 \\
7 & 0.17 & 0.06 & 0.12 \\
$\mathbf{8}$ & 0.05 & 0.05 & 0.04 \\
$\mathbf{9}$ & 0.19 & 0.10 & 0.14 \\
10 & 0.07 & 0.07 & 0.06 \\
11 & 0.07 & 0.11 & 0.05 \\
\hline Citymide & 0.04 & 0.03 & 0.03 \\
\hline
\end{tabular}

represented by only small size classes and while abundant, small trees are relatively unimportant when considering the functionality of the forest (McPherson et al. 1999a).

This representation of tree age suggested that some individual species were heavily planted over a relatively short period and then subsequently abandoned for alternative species. Overall, however, relative age was well distributed, having the majority of trees in smaller size classes poised to replace older trees as their functionality wanes (Richards 1982/1983; McPherson and Rowntree 1989). Conversely, problems arose when approached from a zone segment scale. Different zones depended heavily on particular species of unvarying age. Though these populations were

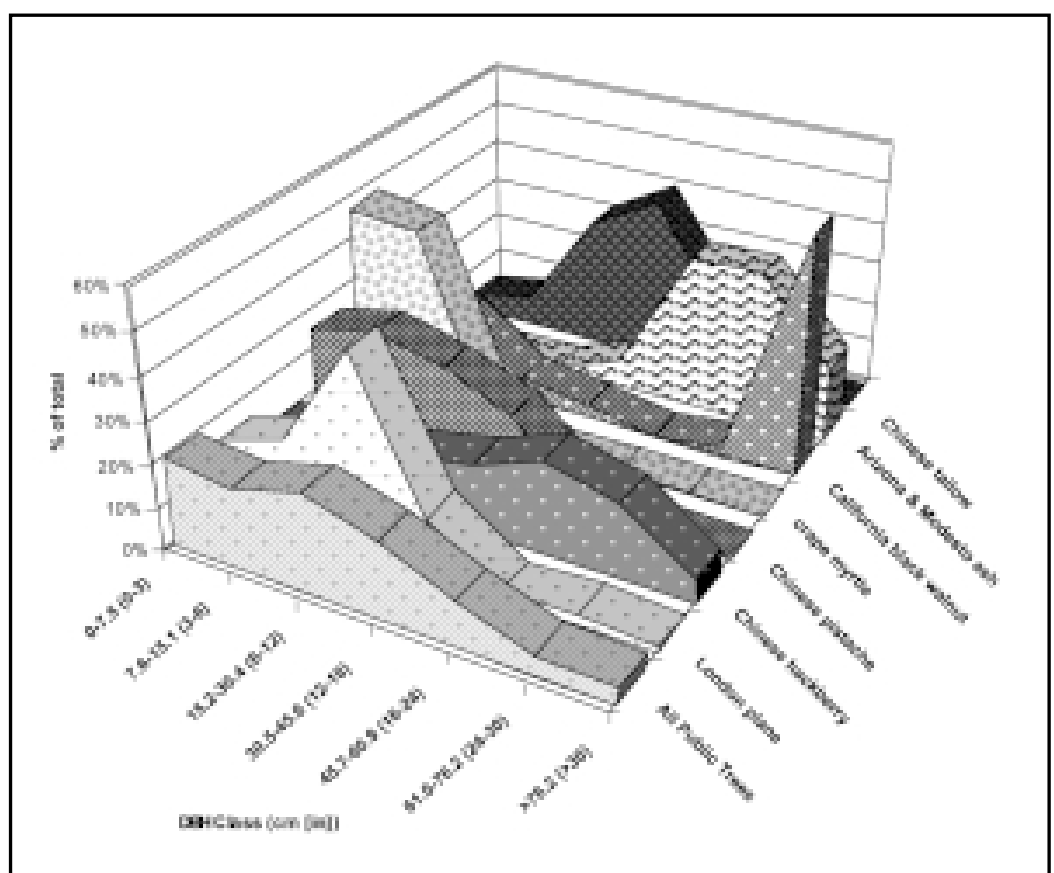

Figure 3. Relative age distribution of selected tree species and total public tree population. large, mature, healthy, and required little maintenance at the time of inventory, their condition is likely to deteriorate over a relatively short period as they mature. These areas will suffer deficiencies in value and sustainability as functional trees age and decline.

Condition. Tree condition indicates both how well trees are managed and their relative performance given sitespecific conditions. Because of neglect and inconsistent management, street trees privately cared for are typically in poorer condition relative to those publicly managed (Bartenstein 1981). In Davis, however, there was little difference between the citywide condition of public and private trees. Trees in "good" condition accounted for approximately $60 \%$ of the population, $32 \%$ were fair, and $8 \%$ poor or dead.

\section{Resource Function and Value}

During the 1999-2000 fiscal year, publicly maintained street trees produced nearly $\$ 1.7$ million in tangible benefits for the residents of Davis (Table 5); less net expenditures of $\$ 449,353$, net benefits were $\$ 1,248,464$ annually. This amounted to an average of $\$ 52.43$ per publicly maintained tree, or approximately $\$ 21.30$ for every resident. Total annual benefits divided by total annual costs yielded a benefit-cost ratio (BCR) of 3.78:1. Therefore, the city's street trees returned $\$ 3.78$ to the community for every $\$ 1$ spent on their management.

The BCR was favorably high in Davis. Forty percent of the annual benefits were attributed to environmental values. Of this amount, energy savings and improved air quality-benefits that are locally realized-were the majority of this value. Though functionally of lesser proportion, reductions in $\mathrm{CO}_{2}$ and stormwater runoff were substantial. Annual increases in property value were the largest benefits produced by street trees in Davis, accounting for $60 \%$ of the total for an annual value of over $\$ 1$ million.

On average, privately maintained trees along the streets of Davis did not perform as well as publicly cared for trees, providing less than $70 \%$ of the net benefits on a per tree basis. The proportionately larger trees in the public tree population accounted for the increased level of benefits.

While species varied in their ability to produce benefits, common characteristics of trees within tree type classes aided in identifying the most beneficial street trees in Davis (Table 6). Comparatively, large trees produced the most benefits, but the average large deciduous tree produced nearly $30 \%$ more than a large conifer, and almost 50\% more than a large broadleaf evergreen. Comparisons within tree types were 
Table 5. Total annual benefits produced by public and private street trees in Davis (weighted averages).

\begin{tabular}{|c|c|c|c|}
\hline Benefi & Totsi (\$) & $\begin{array}{c}\text { \%of Total } \\
\text { Beneft }\end{array}$ & $\begin{array}{c}\text { Average } \\
5 \text { hves }\end{array}$ \\
\hline \multicolumn{4}{|l|}{ Public Sroet Trees } \\
\hline \multicolumn{4}{|l|}{ Emvironmental } \\
\hline Energy & 274,176 & $16 \%$ & 11.52 \\
\hline $\mathrm{CO}_{2}$ & 102,485 & $6 \%$ & 4.30 \\
\hline Air Qualiy & 279,273 & $16 \%$ & 11.54 \\
\hline Stormaater & 24,342 & $1 \%$ & 1.02 \\
\hline Emvironmentsi Sublotsi & 680,277 & $40 \%$ & 28.38 \\
\hline Property Increase & $1.017,538$ & $60 \%$ & 42.74 \\
\hline Puble Tree Tobal & 1699815 & $83 \%$ & $\overline{71,12}$ \\
\hline \multicolumn{4}{|l|}{ Privale Street Trees } \\
\hline \multicolumn{4}{|l|}{ Emvironmental } \\
\hline Enengy & 64,837 & $18 \%$ & 8.94 \\
\hline $\mathrm{CO}_{2}$ & 20,598 & $6 \%$ & 2.84 \\
\hline Air Quality & 44,670 & $13 \%$ & 6.16 \\
\hline Stormazter & 5.441 & $2 \%$ & 0.75 \\
\hline Emvironmentsi Subtotal & 135,546 & $38 \%$ & 18.68 \\
\hline Property Increase & 219,399 & $62 \%$ & 30.24 \\
\hline Private Tree Total & 354,945 & $17 \%$ & 48.92 \\
\hline Totsl Benefr & $2,052,760$ & $100 \%$ & 66.41 \\
\hline
\end{tabular}

more striking; even the youngest of the large-stature deciduous trees produced more annual benefits than mature small-stature trees of the same type. Medium deciduous trees outperformed large broadleaf evergreens and rival the benefit produced by the average large conifer.

The two most important types of street trees in Davis were large- and medium-stature deciduous trees. Figure 4 shows that, while other tree types can and do produce benefits, deciduous trees of large and medium forms produced the greatest benefits.

The values represented in Figure 5 reflect the presence of specific tree types. Due to the prevailing mature largestature deciduous trees in zone segments 5 and 7 , total average annual benefits were high, with even distribution between environmental and aesthetic benefits. On the other hand, zone segments with young tree populations provided relatively few environmental benefits compared to increased property values.

Table 6. Average (weighted) annual benefits (\$) produced by tree types as a function of dbh class $(\mathrm{NP}=$ No public trees present in age class $)$.

\begin{tabular}{|c|c|c|c|c|c|c|c|c|}
\hline \multirow[b]{2}{*}{ Specis } & \multicolumn{7}{|c|}{ DeH chass $[\mathrm{cm}[\mathrm{n}]$} & \multirow[b]{2}{*}{ Total Ang. } \\
\hline & $\begin{array}{l}075 \\
{[0-3]}\end{array}$ & $\begin{array}{c}76-15.1 \\
{[3-6]}\end{array}$ & $\begin{array}{c}152.304 \\
(5-12)\end{array}$ & $\begin{array}{c}305-4566 \\
{[12-18]}\end{array}$ & $\begin{array}{c}45.7-60.9 \\
(18-29)\end{array}$ & $\begin{array}{c}61.0762 \\
2430\end{array}$ & $>762(p 30)$ & \\
\hline Lg Decidous & 26.8 & $\pi 22$ & 12470 & 12548 & 10486 & 957 & 11328 & 9605 \\
\hline Mesi. Deciduaus & 21.68 & 52.51 & 8166 & 8732 & 10429 & 8เ 26 & 9041 & 7000 \\
\hline Sm. Deciduous & 907 & 16.62 & 1484 & 17.75 & 2067 & NP & $N P$ & 1296 \\
\hline Lg Brondesf Evergem & 704 & 2212 & 4953 & 90.45 & 12389 & 11628 & 10992 & 54.42 \\
\hline Med. Broeded Evergeen & 1055 & 27.38 & 5198 & 7583 & 6002 & 10731 & NP & 2990 \\
\hline Sm, Aloadsat Evergeen & 1368 & 2862 & 4108 & 41.06 & 41.08 & NP & 4100 & 3059 \\
\hline If Confes & 1681 & 48.14 & 8209 & 7736 & 79.70 & 96,48 & 10481 & 7061 \\
\hline Med.Coniler & NP & $N$ & NP & $N P$ & NP & NP & NP & NF \\
\hline Sm. Conter & 937 & NP & NP & NP & $9 \pi 5$ & NP & $N^{P}$ & 9.60 \\
\hline Alputictets & 18.28 & 4917 & 92.47 & 9220 & 601.42 & 97.18 & 11165 & 71.12 \\
\hline
\end{tabular}

\section{Resource Management Needs}

The city of Davis had estimated their current street tree population at approximately 15,000 trees. The analysis suggests this was a gross underestimate. As reported here, the number of street trees is nearly $60 \%$ higher than the city's estimate, not including the private trees planted in the ROW that managers must contend with. Optimizing management of these trees, within a limited budget, is contingent upon effective allocation of funds. To that end, this approach allows managers to compare relative management needs among zones and allocate funds accordingly.

Pruning Needs. Understanding species distribution, age structure, and tree condition may aid in determining proper pruning cycle length, but it is important to understand the actual pruning needs of city trees. Not only will this knowledge provide clues to whether or not the pruning cycle is adequate, but it will also identify what level of risk and liability is associated with the city's street tree population. Table 7 displays the significant level of pruning needed by Davis's public trees. Overall, $17 \%$ of the trees needed maintenance in the form of pruning, and more than 3\% were categorized as high priority. By zone segment, however, these percentages were sometimes much higher $(>30 \%$ in zones 4 and 5). Zone segments 2 and 10 were pruned in 1999 and accordingly had lower pruning needs $(<10 \%)$ than other zones.

Results also suggested that pruning needs are disproportionately distributed among species. While not ideal, utilizing "species pruning" to target specific tree species could potentially reduce the total number of trees needing pruning over the short term until adequate resources are established to allow for the ideal pruning cycle. For example, in zone segment 5, the pruning of Arizona and Modesto ash along with honey locust (Gleditsia triacanthos) would reduce the number of trees needing pruning to $20 \%$ of estimated levels. In zone 4, pagoda represented more than half of the estimated pruning needs and $70 \%$ of those requiring highpriority pruning.

Similarly, certain management practices can be assessed and targeted for remedy. Citywide it was estimated that approximately $4 \%$ of all public trees possessed stakes that were damaging to the tree and therefore required removal. If one considers that about 20\% of all public trees fell into the young tree dbh class size ( 0 to $15.2 \mathrm{~cm}$ ), and the vast majority of stakes were found on these trees, then $20 \%$ of these trees had problems associated with 


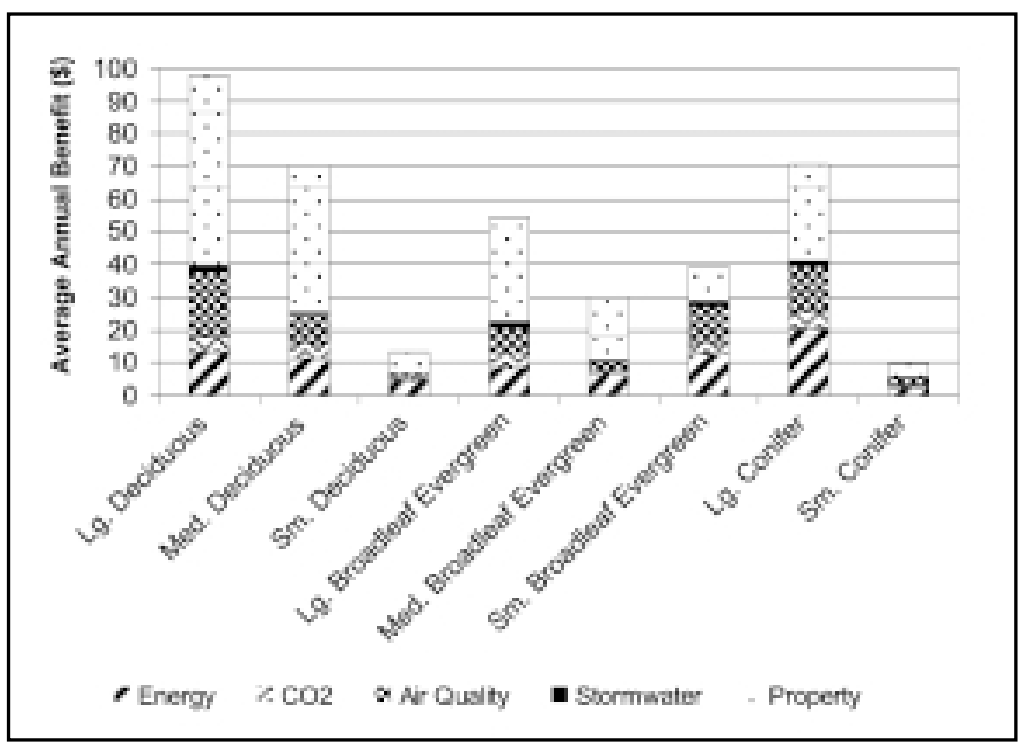

Figure 4. Average annual environmental benefits of a single public tree by tree type.

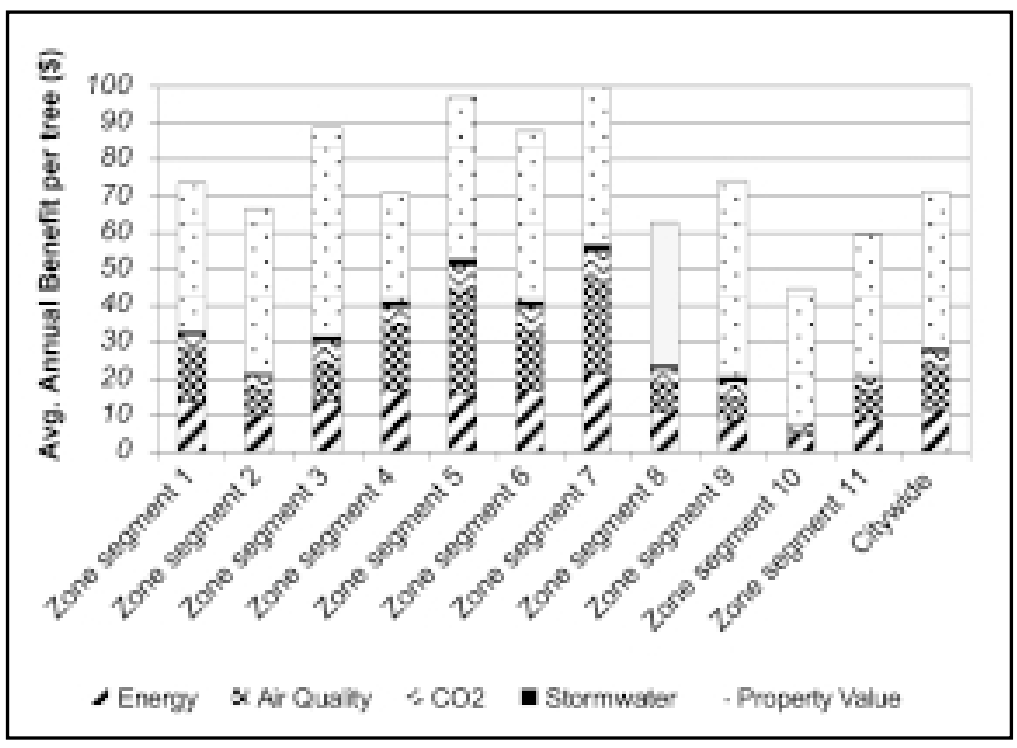

Figure 5. Average annual benefits by zone segment.

staking, suggesting that care of young trees was not adequate in this respect. Either resources may not have been available to attend to all newly out-planted trees on a yearly basis or techniques employed may have been improper.

Removals and Replacement Plantings. Richards (1982/ 1983) defined stability of a street tree population as having a low probability that the number of functional trees will decline over the foreseeable future to the point of disrupting both the functional values trees provide and the management allocations needed for their management.

Due to the high costs of mitigation and loss of benefits, hazard trees are one element that can disrupt overall stability.
Hazardous trees, though, were an infrequent occurrence in Davis. There were only 121 trees in this category citywide; public trees accounted for approximately 100 of the 121 . Of these, $60 \%$ were California walnut and 20\% were Japanese pagoda. The aging walnuts (Figure 3) were found in zone 1 , and pagoda trees were limited to zone 4 where they accounted for $34 \%$ of the zone population.

While low numbers of hazard trees, citywide, may indicate a healthy population, stability must be weighed according to the specific attributes of management zones and, on a smaller scale, blocks and streets. Diversity, condition, pruning needs, and relative age distribution of these street tree stands are all considerations integral to understanding population stability: Which species are too heavily relied on, ill-adapted, or lacking in age complexity?

Comparing the age distributions in Figure 3 with species prevalence in Table 7 suggests that heavy reliance on populations of specific speciesmoving past the age of functionality into senescence-poses an imminent risk to the stability of several zones. For example, the aging populations of Arizona and Modesto ash along with Chinese hackberry were the most prevalent species in zone 5-a zone with the second highest average annual benefits per tree. With the combined populations comprising $45 \%$ of the total zone population, it would behoove the city to initiate a strategic removal and replacement program to prevent these trees from becoming hazards, requiring wholesale removal and drastic loss of stand functionality.

New Plantings. Assuming $15 \mathrm{~m}$ spacing, Davis's citywide stocking rate was nearly maximized at 97\% of full stocking - a statistic that has been rarely matched in the literature, where city stocking rates have been assessed to average between approximately 40\% and 60\% (Wray and Prestemon 1983; McPherson and Rowntree 1989).

Of course, the concept of stocking involves more than tree density alone. Available planting space, size of existing trees, and site conditions all have a role. Therefore, to better evaluate the actual number of available planting spaces, the city's targeted level of one street tree per residential lot-where a residential lot averaged 24 m citywide-was observed for "void" spaces (Table 7). By this measurement, almost $8 \%$ of Davis's planting sites were void of trees. Only the downtown center (zone segment 6) was observed to be fully stocked. Newer neighborhoods such as zones 10 and 11 exhibited the most available planting spaces. Planting management zones with the greatest need will, in time, allow for more equity in the distribution of average annual benefits by zone (Figure 5). 
Table 7. Summary of zone management needs.

\begin{tabular}{|c|c|c|c|c|c|c|}
\hline & \multicolumn{3}{|c|}{$\begin{array}{l}\text { Destribubon of the thee mostprevalcrit publo speoes } \\
\qquad \text { (" of total zone populition) }\end{array}$} & \multirow{2}{*}{$\begin{array}{l}\text { Estd. blat } \\
\text { \#ct } \\
\text { plartste } \\
\text { spaces }\end{array}$} & \multirow{2}{*}{$\begin{array}{l}\text { \% of } \\
\text { populaton } \\
\text { roquires } \\
\text { prining }\end{array}$} & \multirow{2}{*}{$\begin{array}{r}\text { Sof poputabon } \\
\text { noqures } \\
\text { immodise } \\
\text { atrontion }\end{array}$} \\
\hline & 1st & $2 \mathrm{nd}$ & 3 rd & & & \\
\hline Zone 1 & back wainut $\{20\}$ & Chineces aliow [14] & Chinees pistacthe (6) & 305 & $19 \%$ & $4 \%$ \\
\hline Zone 2 & London plane $(17)$ & Brationd pear (1) & crape mprte (16) & 209 & $\%$ & $2 \%$ \\
\hline Zone 3 & ginko (12) & adp ree $(9)$ & horvey locast (6) & 79 & $21 \%$ & $6 \%$ \\
\hline Zone 4 & Jsponcese pagoda [34] & Japanese zelkova(16) & Chinees pistacthe (6) & 45 & $34 \%$ & $11 \%$ \\
\hline Zones & Anzore ach $(17)$ & Modesto ash (14) & Chincese hackbenry $[14]$ & 11 & $37 \%$ & $5 \%$ \\
\hline Zone 6 & London plane (25) & Moraireash (22) & crape myrte $(10)$ & 0 & $20 \%$ & $3 \%$ \\
\hline Zone? & 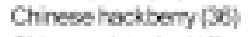 & Morainessh (12) & Eurocesen haxkberry (8) & 200 & $29 \%$ & $3 \%$ \\
\hline Zone \& & Chinese pestache(13) & Londonptene(10) & Eurocesen hormbesm [7] & 369 & $17 \%$ & $2 \%$ \\
\hline Zense 9 & Lendbn plane (40) & scuthem magrolia (14) & Chincese hackberry $(7)$ & $\mathscr{2}$ & $10 \%$ & $1 \%$ \\
\hline$Z e n=10$ & Lendenglane (13) & Fuawoos ash (13) & crace mate [9] & 708 & $8 \%$ & $2 \%$ \\
\hline Zens 11 & Brationd peor (16) & Londengtane (12) & Chineses gestacthe $<10$ & 452 & $13 \%$ & $0 \%$ \\
\hline Ciswids & Londen glane (122) & Chineses galache (76) & Chineses hachleery (6.2) & 2,381 & $17 \%$ & $3 \pi$ \\
\hline
\end{tabular}

(\$14.84) in

Davis was overvalued by $3.3 \%$, or a total of $\$ 0.49$. While small discrepancies in growth between the two cities is expected, this was an important assumption that limits further extension of the Modesto-

\section{Assumptions and Limitations}

One premise behind the extension of Modesto's cost-benefit analysis to Davis is that street trees' growth response to climatic, pedologic, and human influences (e.g., pruning) is similar in both cities. For example, this assumption implies that a tree of species $X$ in Modesto at 15 years of age and 17 $\mathrm{cm}$ dbh will possess the same crown and leaf area measurements of a tree of species $X$ with a dbh of $17 \mathrm{~cm}$ in Davis; species $X$ in both cities was assumed to have similar allometric growth with respect to dbh.

To validate this supposition, crown diameter data for three species (pistache, crape myrtle, and Modesto ash) were tested for differences between the two city populations. As expected, ANOVA, conducted using SAS PROC MIXED, suggests that differences between the two populations are not exactly equal. Contrast analysis of slope and intercept means for each of the three species are presented in Table 8.

Assuming a 5\% significance level, both the pistache and crape myrtle populations appeared to differ, while differences between the two ash populations were not evident. To better understand the magnitude of the inequalities, 95\% confidence intervals (CI) were constructed for each of the three species (Figure 6). Low- and high-interval overlap negate any large differences perceived for populations of either the pistache or ash. Confidence is high, however, that crape myrtle has a larger mature crown diameter-and presumably greater functional benefits-in Modesto than Davis. Assuming a direct correlation between crown diameter and benefits accrued, at 95\% confidence, total annual benefits for a single crape myrtle at $24 \mathrm{~cm}$ dbh

Table 8. Equality of slopes and intercepts of three species among populations in Davis and Modesto.

\begin{tabular}{lccc}
\hline Species & dfidf & $F$ & $p$ \\
\hline Pistacia chinensis & $2 / 204$ & 4.38 & 0.0137 \\
Lagerstroemia indica & $2 / 162$ & 7.95 & 0.0005 \\
Fraxinus velutina 'Modesto' & $2 / 61$ & 1.73 & 0.1865 \\
\hline
\end{tabular}

specific analysis to cities that may differ in species and their allometric response to factors affecting growth.

Tree distribution —orientation and distance from airconditioned space-affects the potential amount of building energy savings trees provide. Factors that affect tree distribution include average lot size, building setback from curb, street layout (i.e., grid versus curvilinear block pattern), and city planting practices. Though these data can be collected in the sample inventory, adjusting cooling savings is complex and has a relatively small impact on overall cooling savings. Modesto's street tree distribution was assumed for the city of Davis.

Further, the structure of many small North American cities lends itself to the sampling technique and analysis used for this approach. Further testing is needed to ascertain its practicality and applicability in other parts of the world where city street and development patterns may differ.

\section{CONCLUSION}

A sample inventory technique provided sufficient data to describe structural characteristics of an urban street tree population with enough accuracy to assess the environmental benefits they provide using tree growth data and benefits from a nearby city. In addition, the BCR was calculated and management needs were identified. Although the sample inventory technique employed was based on established statistical methods, there is no doubt that an element of precision was lacking due to the degree of assumptions made, though the intent of quantifying benefits was not to account for each penny. Rather, this analysis provided a general accounting of the benefits produced by street trees-an accounting with an accepted degree of uncertainty-that can nonetheless provide a platform from which decisions can be made.

Useful as a guideline for communities with few resources, this approach can be a valid starting point for long-term community forest 


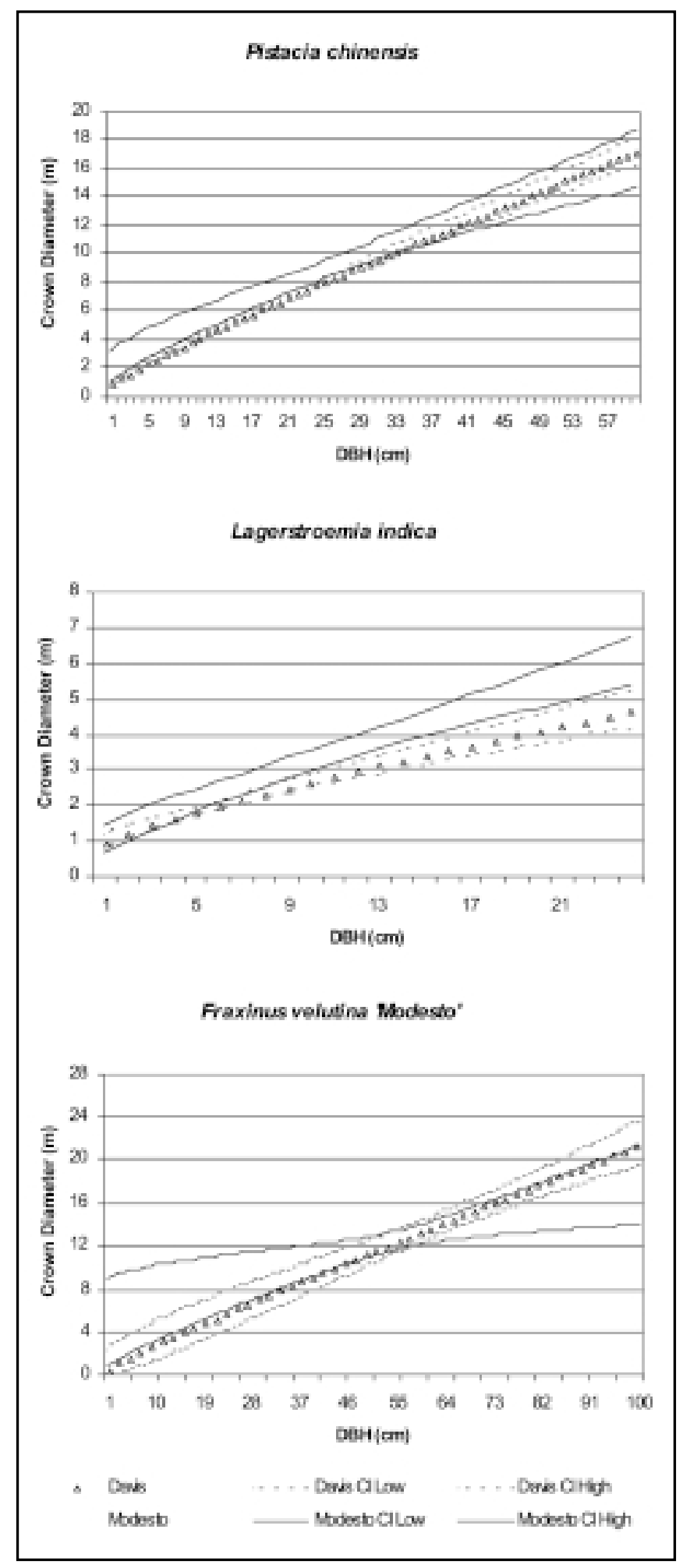

Figure 6. Comparison of two populations of three prevalent street trees using square root straight-line transformations and $95 \%$ confidence intervals (CI). management, as well as spurring interest and investment in community tree planting and care. Any community with similar climate and tree composition can use the approach outlined in this report to conduct their own analysis. As the USDA Forest Service's Center for Urban Forest Research conducts additional research to develop Tree Guides in other locales, communities in those regions can apply this approach to discover and realize the full potential of their street trees.

\section{LITERATURE CITED}

Anderson, L.M., and H.K. Cordell. 1988. Influence of trees on residential property values in Athens, Georgia (U.S.A.): A survey of actual sales prices. Landscape Urban Plann. 15(1988): 153-164.

Bartenstein, F. 1981. The future of urban forestry. J. Arboric. 7(10):261-267.

California Air Resources Board. 2000. Emission Reduction Offset Transaction Cost Summary Report for 1999. State of California Environmental Protection Agency.

2001. Emission Reduction Offset Transaction Cost Summary Report for 2000. State of California Environmental Protection Agency.

California Energy Commission. 1994. Electricity Report. State of California, Energy Commission, Sacramento, CA.

City of Davis. 2001. General City Statistics. http://www. city.davis.ca.us/aboutdavis/statistics.htm (accessed 1/19/01).

City of Olympia. 1995. Impervious Surface Reduction Study, Final Report. City of Olympia, WA, Public Works Department, Water Resources Department. 207 pp.

Clark, J.R., N.P. Matheny, G. Cross, and V. Wake. 1997. A model of urban forest sustainability. J. Arboric. 23(1):17-30.

Cochran, W.G. 1977. Sampling Techniques (3rd Ed.). John Wiley \& Sons, New York, NY. 428 pp.

Department of Finance, CA. 2001. City/County Population Estimates with Annual Percent Change. http://www. dof.ca.gov:8080/html/demograp/e-1 table.htm (accessed $1 / 19 / 01)$.

Jaenson, R., N. Bassuk, S. Schwager, and D. Headley. 1992. A statistical method for the accurate and rapid sampling of urban street tree populations. J. Arboric. 18(4):171-183.

McPherson, E.G. 2000. Expenditures associated with conflicts between street tree root growth and hardscape in California. J. Arboric. 26(6):289-297.

McPherson, E.G., and R.A. Rowntree. 1989. Using structural measures to compare twenty-two US street tree populations. Landscape J. 8:13-23.

McPherson, E.G., D.W. Nowak, G. Heisler, S. Grimmond, C. Souch, R. Grant, and R. Rowntree. 1997. Quantifying urban forest structure, function, and value: The Chicago Urban Forest Climate Project. Urban Ecosyst. 1:49-61. 
McPherson, E.G., J.R. Simpson, P.J. Peper, and Q. Xiao. 1999a. Benefit-Cost Analysis of Modesto's Municipal Urban Forest. Western Center for Urban Forest Research and Education, USDA Forest Service. 43 pp.

_ 1999b. Tree Guidelines for San Joaquin Valley Communities. Local Government Commission, Sacramento, CA. 64 pp.

McPherson, E.G., J.R. Simpson, P.J. Peper, K.I. Scott, and Q. Xiao. 2000. Tree Guidelines for Coastal Southern California Communities. Local Government Commission, Sacramento, CA. 98 pp.

McPherson, E.G., J.R. Simpson, P.J. Peper, Q. Xiao, D.R. Pettinger, and D.R. Hodel. 2001. Tree Guidelines for Inland Empire Communities. Local Government Commission, Sacramento, CA. 115 pp.

McPherson, E.G., S.E. Maco, J.R. Simpson, P.J. Peper, Q. Xiao, A. VanDerZanden, and N. Bell. 2002. Western Washington and Oregon Community Tree Guide: Benefits, Costs, and Strategic Planting. International Society of Arboriculture, Pacific Northwest Chapter, Silverton, OR.

Natural Resources Conservation Service (NRCS). 1986. Urban Hydrology for Small Watersheds, Technical Release 55 (2nd Ed.). United States Department of Agriculture, Natural Resources Conservation Service, Conservation Engineering Division.

Pacific Gas \& Electric Company. 2001a. Schedule E-1Residential Service. http://www.pge.com/customer_services/ business/tariffs/pdf/E-1.pdf (accessed 4/9/01).

Pacific Gas \& Electric Company. 2001b. Gas Rate History. http://www.pge.com/customer_services/business/tariffs/ GRF.SHTML\#RESGAS (accessed 4/9/01)

Peper, P.J., and E.G. McPherson. 1998. Comparison of five methods for estimating leaf area index of open-grown trees. J. Arboric. 24(2):98-111.

Peper, P.J., E.G. McPherson, and S.M. Mori. 2001. Equations for predicting diameter, height, crown width, and leaf area of San Joaquin Valley street trees. J. Arboric. 27(6):306-317.

Richards, N.A. 1982/1983. Diversity and stability in a street tree population. Urban Ecol. 7:159-171.

Sanders, R.A. 1981. Diversity in the street trees of Syracuse, New York. Urban Ecol. 5:33-43.

Simpson, E.H. 1949. Measurement of diversity. Nature. 163:688.

U.S. Census Bureau. 1995. Urban and Rural Definitions. http://www.census.gov/population/censusdata/urdef.txt (accessed 9/12/01).

Wells, F.A. 1972. Soil Survey of Yolo County, California. USDA, Soil Conservation Service, Woodland, CA. 102 pp.

Wray, P.H., and D.R. Prestemon. 1983. Assessment of street trees in Iowa's small communities. Iowa State J. Res. 58(2):261-268.

Yolo County Association of Realtors. 2001. Home Sales Report: Single family home in the city of Davis between 7/1/99-6/30/00.
Acknowledgments. This research was made possible with funding from the California Department of Forestry and Fire Protection and the city of Davis, California. Technical assistance was provided by Paula Peper and Jim Simpson [Center for Urban Forest Research (CUFR)], Qingfu Xiao (UC Davis Dept. of LAWR), and Sylvia Mori (USFS PSW). Tommy Mouton (CUFR), Jin Cho, and Sterling Smith (UC Davis) aided with data collection. Drs. Dave Burger (UC Davis) and Larry Costello (UC Cooperative Extension) provided helpful direction and reviews of this work. Without support from Bob Cordrey (City of Davis), this project was impracticable.

\section{USDA Forest Service \\ Pacific Southwest Research Station \\ Center for Urban Forest Research \\ clo Environmental Horticulture \\ One Shields Avenue \\ University of California, Davis \\ Davis, CA 95616, U.S.}

Corresponding author: Scott Maco.

Résumé. Cette étude fait la démonstration d'une approche pour quantifier la structure, les bénéfices et les coûts associés aux populations d'arbres de rues dans les municipalités aux ressources limitées qui n'ont pas d'inventaire d'arbres. En se servant de la municipalité de Davis en Californie comme modèle, les données existantes sur les bénéfices et les coûts des arbres municipaux ont été appliquées face aux résultats d'un inventaire par échantillonnage des arbres publics et privés de rues de la ville. Les résultats indiquent que Davis maintien environ 24000 arbres publics de rues qui procurent annuellement 1,2 millions de dollars en bénéfices environnementaux nets et en valeurs nettes sur les propriétés, et ce avec un ratio bénéficecoût de 3,8:1. La ville peut améliorer la stabilité à long terme de cette ressource en gérant par zones son entretien, ses nouvelles plantations et le rajeunissement des populations.

Resumen. Este estudio logra una aproximación para cuantificar la estructura, beneficios y costos de poblaciones de árboles urbanos en comunidades de recursos limitados sin inventarios de árboles. Se usó la ciudad de Davis, California, EE.UU., como un modelo, aplicando los datos existentes de costos y beneficios de árboles municipales a los resultados de una muestra de inventario de los árboles públicos y privados de la ciudad. Los resultados indican que Davis mantiene aproximadamente 24,000 árboles públicos que proporcionan $\$ 1.2$ millones en beneficios ambientales netos y valor de la propiedad, con una relación costo-beneficio de 3.8:1. Con base en una zonificación, la ciudad puede mejorar la estabilidad a largo plazo de su recurso, con mantenimiento, plantaciones nuevas y rejuvenecimiento de los rodales 